\title{
Cost-volume-profit ratio of concentrate supplements in finishing diets for beef cattle
}

\section{Relação custo-volume-lucro de suplementos concentrados em dietas de terminação de bovinos de corte}

\author{
Marcell Patachi Alonso ${ }^{1 *}$; Tatiane Beloni ${ }^{1}$; Eduardo Henrique Bevitori \\ Kling de Moraes ${ }^{2}$
}

\begin{abstract}
The supplementation of the animals' diet can increase the production costs of beef cattle, directly affecting the results of the production system. Using the cost-volume-profit ratio, this study aimed to determine the best level of replacement of corn by pearl millet in the concentrate supplementation of beef cattle finished in a crop-livestock integration system. Based on a previous study, we investigated the production performance of 64 uncastrated steers of an average age of 20 months and an initial average body weight of $388 \pm 26 \mathrm{~kg}$ based on cost for the consumption of four different supplements distinguished by the amounts of pearl millet grain replacing corn grain $(0 \%, 33 \%, 66 \%$ and $100 \%)$. The unit contribution margin, accounting and financial break-even points, margin of safety, and shutdown point were used as the components of the cost-volume-profit ratio in a criterion for determining the optimal supplementation strategy. The results showed that intermediate replacement levels $(33 \%$ and $66 \%$ ) can provide a greater return for the amortization of fixed expenses and profit generation and that cheaper supplements may not generate financial returns to the system. Therefore, a systemic costvolume-profit analysis is useful in experimental evaluations. The concentrate feed supplement with $33 \%$ of corn replaced by pearl millet provides the greatest profitability to the production system.
\end{abstract}

Key words: Accounting. Costs. Livestock. Supplementation.

\section{Resumo}

A suplementação da dieta animal pode aumentar os custos de produção de bovinos de corte, refletindo diretamente nos resultados do empreendimento pecuário. Diante disto, o objetivo deste estudo foi determinar, por meio da relação custo-volume-lucro, o melhor nível de substituição de grão de milho pelo grão de milheto no suplemento concentrado de bovinos de corte, terminados em sistema de integração lavoura e pecuária. Foram associados, com base em um estudo prévio, os desempenhos produtivos de 64 novilhos não castrados, com média de idade de 20 meses e o peso corporal médio inicial de $388 \pm$ $26 \mathrm{~kg}$, aos custos relacionados ao consumo de quatro diferentes suplementos distinguidos por níveis de grão de milheto em substituição ao grão de milho $(0,33,66$ e $100 \%)$. Considerou-se margem de contribuição unitária, ponto de equilíbrio (contábil e financeiro), margem de segurança e ponto de fechamento como componentes da relação custo-volume-lucro no critério de determinação sobre as estratégias de suplementação. Os resultados demonstraram que substituições intermediárias ( 33 e 66\%), podem promover maior retorno para amortização dos gastos fixos e geração de lucro e, que suplementos

${ }^{1}$ Drs., Ciências, Programa de Pós-Graduação em Ciência Animal e Pastagens, Universidade de São Paulo, ESALQ/USP, Piracicaba, SP, Brasil. E-mail: marcell.alonso@usp.br; tatbeloni@gmail.com

2 Prof. Dr., Programa de Pós-Graduação em Zootecnia, Universidade Federal de Mato Grosso, UFMT, Sinop, MT, Brasil. E-mail: edukling@ufmt.br

* Author for correspondence 
mais baratos podem não representar melhores resultados financeiros ao sistema. Portanto, a análise sistêmica da relação custo-volume-lucro se apresenta útil em avaliações experimentais. O suplemento alimentar concentrado contendo o nível de substituição de 33\% do grão de milho pelo grão de milheto, apresenta maior rentabilidade ao sistema de produção.

Palavras-chave: Contábil. Custos. Pecuária. Suplementação.

\section{Introduction}

The emergence, consolidation, and solidity of rural businesses in an economy under constant change require companies to make decisions not only based on animal performance, but also in compliance with a rigorous control of production costs to aid managers' actions.

There are two basic forms of generating financial gains from an economic activity. It is possible to elevate the sale price of a product, which may lead to changes in its demand, or a work plan can be implemented with which costs are reduced and production is increased, thereby increasing profits without a direct dependence on the demand factor (FIGUEIREDO et al., 2007).

Under this premise, livestock production conducted according to the concept of cost reduction, especially the feeding, guides the fattening of cattle at pasture-based production systems. However, for a high level of animal performance to be attained in such conditions, supplementary feeding sources are necessary, which invariably leads to an increase in production costs.

A balanced formulation of supplements through inclusions, reductions, and replacements of ingredients makes it possible to lower the animal feeding cost. Given that the supplementation of diets containing corn grain as an energy ingredient may raise production costs, substituting alternative sources like pearl millet grain for corn may contribute to reducing costs without decreasing the animal production performance (ALONSO et al., 2013).

Of the several available approaches to cost management, a cost-volume-profit (CVP) analysis is highly recommendable as it reveals the behavior of costs and profit in relation to the size of production. However, this analysis is still little used in accounting appraisals in the scope of livestock production. This managerial tool enables the projection of the results to several levels of sales, prices, production volumes, costs structures and expenses (STARK, 2008; WARREN et al., 2008), providing important information about variables internal and external to the area of the economic activity, and aiding the decision-making process in the diverse operations performed by a company.

The objective of this study was to present a CVP analysis as a criterion for deciding on a strategy of concentrate supplementation for beef cattle finished in a crop-livestock integration system.

\section{Materials and Methods}

The study was conducted at a rural property in the municipality of Santa Carmem, northern Mato Grosso State, Brazil, from June to September 2010. The experimental area is located at geographic coordinates $12^{\circ} 03^{\prime} 52.07 " \mathrm{~S}$ and $55^{\circ} 21^{\prime} 16.92^{\prime \prime} \mathrm{W}$ and an elevation of $386 \mathrm{~m}$.

The methodological descriptions and data for this study were based on those proposed by Alonso et al. (2013). Four treatments were tested, consisting of dietary supplements with different levels of corn grain being replaced by pearl millet grain (Table 1). We used 64 uncastrated steers - 32 crossbred (Holstein x Nelore) and 32 Nelore - with an average age of 20 months and initial body weight of $388 \pm$ $26 \mathrm{~kg}$.

To compute the accounting variables of this study, data pertaining to the average daily weight gain $\left(\mathrm{kg}\right.$ animal ${ }^{-1}$ day $\left.^{-1}\right)$ and total weight gain $(\mathrm{kg}$ 
animal $^{-1}$ ) were used, based on the results of Alonso et al. (2013).

The average supplement dry matter (DM) intake by the animals was calculated according to Alonso et al. (2017) for the four replacement levels, as shown in eq. (1):

$$
\mathrm{SDMI}=\mathrm{TDMI}-\mathrm{PDMI}
$$

Where SDMI is the average voluntary intake of dry matter from the supplement $\left(\mathrm{kg}\right.$ animal ${ }^{-1}$ day $\left.^{-1}\right)$, TDMI is the average voluntary intake of total dry matter $\left(\mathrm{kg}\right.$ animal $^{-1}$ day $\left.^{-1}\right)$, and PDMI is the average voluntary intake of dry matter from the pasture $(\mathrm{kg}$ animal $^{-1}$ day $^{-1}$ ).

Table 1. Centesimal composition and average cost of supplements on a fresh-matter basis.

\begin{tabular}{|c|c|c|c|c|}
\hline \multirow{2}{*}{ Ingredient } & \multicolumn{4}{|c|}{ Replacement level } \\
\hline & 0 & 33 & 66 & 100 \\
\hline & \multicolumn{4}{|c|}{--------------------------------- $\%$} \\
\hline Mineral mixture & 2.00 & 2.00 & 2.00 & 2.00 \\
\hline Ground soybean waste & 55.27 & 52.68 & 50.09 & 45.78 \\
\hline Ground corn & 42.73 & 31.08 & 19.43 & - \\
\hline \multirow[t]{2}{*}{ Ground pearl millet } & - & 14.24 & 28.48 & 52.22 \\
\hline & \multicolumn{4}{|c|}{ - } \\
\hline Average cost & 0.13 & 0.13 & 0.12 & 0.10 \\
\hline
\end{tabular}

Source: Created by the author, based on Alonso et al. (2013).

*Note: Values determined in September 2010.

Based on the SDMI values and on the percentage DM values from the treatments described by Alonso et al. (2017), we determined the voluntary intake of supplement on a fresh-matter basis using eq. (2):

$$
\mathrm{SFMI}=\mathrm{SDMI} /(\mathrm{DM} / 100)
$$

Where SFMI is the average voluntary intake of supplement fresh matter $\left(\mathrm{kg}\right.$ animal $\left.{ }^{-1} \mathrm{day}^{-1}\right)$ and DM is the dry matter content of the supplements (\%). SFMI was used in the composition of the variable costs related to the feeding of the animals.

Revenue was defined as the value resulting from the sale of the animals, relative only to the total weight gain obtained in the experiment. The price adopted was that of September 2010, considered the average monthly nominal price of the arroba (@) of fattened cattle (paid cash), ignoring the Rural Workers Assistance Fund (Fundo de Assistência ao
Trabalhador Rural, FUNRURAL), in the middlenorthern macro-region of Mato Grosso State: USD 48.15 (IMEA, 2010).

Expenses were defined based on the collection of data in the field, with the annual depreciation rates and useful life of the assets determined according to the description by Marion (2010) and by Normative Instruction RFB $\mathrm{n}^{\circ} 1700$ (BRASIL, 2017). Expenses were classified into depreciation, fixed costs, variable costs, and total costs.

Animals, forages, facilities, and equipment in the area - handling corral, storage shed, conventional fence, pasture, pickup truck, thin cattle, and horse were disregarded when calculating the composition of fixed costs throughout the experimental period, but were considered in the determination of depreciation as a function of their wear over the experimental period. 
After the total expenses on the supplementation of the animal diets during the experimental period were estimated, a CVP analysis was performed by determining the unit contribution margin, accounting and financial break-even points, and margin of safety (WERNKE, 2004). Additionally, the shutdown point was also determined for a better evaluation of the results.

The unit contribution margin is a concept directly linked to CVP analysis, represented by the value resulting from the sale of a product after variable costs and expenses related to it are deducted. The following components were considered variable costs and expenses: identification earrings, fuel and oil, electrical energy, endectoparasiticides, vaccines, and supplementation. The unit contribution margin was determined based on Bornia (2010), expressed by eq. (3):

$$
\mathrm{UCM}=\mathrm{USP}-\mathrm{VUC}
$$

Where UCM is the unit contribution margin $\left(\mathrm{USD} @^{-1}\right.$ ), USP is the unit sale price (USD $@^{-1}$ ), and VUC is variable unit costs (USD $@)^{-1}$ ).

The accounting break-even point corresponds to the minimum level - in monetary units or quantity of product - to be produced and sold so that all costs are paid and no profit exists (SOUZA; CLEMENTE, 2011); see eqs. (4) and (5). In this case, fixed costs were considered to be the expenditures for the following components plus the depreciation of tangible assets in the experimental period: drinker, troughs, opportunity cost, fence energizer, labor, and pistol syringes.

$$
\begin{gathered}
\mathrm{ABPq}=(\mathrm{FC}+\mathrm{FE}) / \mathrm{UCM} \\
\mathrm{ABP}_{\$}=\mathrm{ABPq} \times \mathrm{USP}
\end{gathered}
$$

Where $\mathrm{ABPq}$ is the accounting break-even point (@), FC are the fixed costs (USD), FE are the fixed expenses (USD), UCM is the unit contribution margin (USD @ ${ }^{-1}$ ), $\mathrm{ABP}_{\$}$ is the accounting breakeven point (USD), and USP is the unit sale price (USD@-1).
The financial break-even point, in turn, is the volume of sales necessary (in quantity or monetary units) for the total revenue to offset the expenses payable by the company (cash charges) (BRUNI; FAMÁ, 2010); see eqs. (6) and (7). In this scenario, non-cash charges were considered to be the depreciation values.

$$
\begin{gathered}
\mathrm{FBPq}=[(\mathrm{FC}+\mathrm{FE})-\mathrm{NCC}] / \mathrm{UCM} \\
\mathrm{FBP}_{\$}=\mathrm{FBPq} \times \mathrm{USP}
\end{gathered}
$$

Where FBPq is the financial break-even point (@), NCC are the total non-cash charges (USD), and $\mathrm{FBP}_{\$}$ is the financial break-even point (USD).

The margin of safety is the number or index of sales above the company's break-even point, that is, by how much sales can decrease without resulting in losses (BRUNI; FAMÁ, 2010). This accounting variable can be expressed as a quantity of products, in monetary units, or in percentage terms, according to eqs. (8) and (9):

$$
\begin{gathered}
\mathrm{MSq}=\mathrm{QCS}-\mathrm{ABPq} \\
\mathrm{MS}_{\$}=\mathrm{MSq} \times \mathrm{USP}
\end{gathered}
$$

Where MSq is the margin of safety expressed as a quantity (@), QCS is the quantity of current sales (@), ABPq is the accounting break-even point (@), and $\mathrm{MS}_{\mathrm{S}}$ is the margin of safety in monetary units (USD).

The shutdown point is an indicator that gives the minimum volume of sales that justifies the continuation of a company's activities or of the production of a given product. Thus, the shutdown point corresponds to the level of activity at which the contribution margin equals the fixed costs that can be eliminated (or avoided) in the short term should the company end its activities (BORNIA, 2010); see eq. (10).

$$
\mathrm{SP}=\mathrm{FAC} / \mathrm{UCM}
$$

Where SP is the shutdown point in units of the product (@), FAC is the fixed avoidable costs (USD), and UCM is the unit contribution margin (USD @ ${ }^{-1}$ ). 
In this study, among other attributes, we did not consider the taxation of the livestock production as a function of the variability of rates, contributions, and taxes on the production and sale of animals: the type of tax-paying producer (natural person or legal entity), degree of use of the estate for the determination of the rural territorial tax, and type of purchaser of a sale of animals. This assumption was made in an attempt to standardize the data, facilitating the interpretation of and inference from the results.

\section{Results and Discussion}

Aftertheacquisition ofanimals, feedingrepresents a large part of the rearing costs (POSSAMAI et al., 2015). Thus, a careful evaluation of the costs in the adoption of the concentrate-supplementation technique is of paramount importance for better strategies to be implemented in the field. The effect of treatments on the performance of the animals made it possible to determine the costs pertaining to the finishing of cattle under the adoption of four supplementary compositions (Table 2 ).

Table 2. Composition of fixed, variable, and total costs and depreciation in the production of beef cattle supplemented with increasing levels of corn replaced by pearl millet.

\begin{tabular}{|c|c|c|c|c|}
\hline \multirow{2}{*}{ Description } & \multicolumn{4}{|c|}{ Replacement level (\%) } \\
\hline & 0 & 33 & 66 & 100 \\
\hline & \multicolumn{4}{|c|}{ 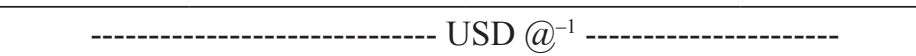 } \\
\hline Improvements and equipment $^{(1)}$ & 11.66 & 11.51 & 11.93 & 13.76 \\
\hline Labor $^{(2)}$ & 3.08 & 3.05 & 3.16 & 3.64 \\
\hline Opportunity $\operatorname{cost}^{(3)}$ & 3.82 & 3.78 & 3.91 & 4.51 \\
\hline Fixed costs (FC) & 18.56 & 18.34 & 19.00 & 21.91 \\
\hline Feeding $^{(4)}$ & 17.55 & 16.39 & 15.90 & 16.64 \\
\hline Health $^{(5)}$ & 0.63 & 0.63 & 0.65 & 0.75 \\
\hline General expenses ${ }^{(6)}$ & 1.01 & 1.00 & 1.04 & 1.20 \\
\hline Variable costs (VC) & 19.20 & 18.02 & 17.60 & 18.60 \\
\hline Depreciation (D) & 6.64 & 6.56 & 6.79 & 7.84 \\
\hline Total cost $(\mathrm{FC}+\mathrm{VC}+\mathrm{D})$ & 44.39 & 42.91 & 43.39 & 48.35 \\
\hline
\end{tabular}

Source: Original research results.

*Note: ${ }^{(1)}$ Electric fence, fence energizer, Australian drinker, half-drum troughs, and pistol syringe. ${ }^{(2)}$ Labor and social charges for $1.5 \mathrm{~h} \mathrm{day}^{-1} \cdot{ }^{(3)}$ Rent for pasture, USD 8.73 animal $^{-1} .{ }^{(4)}$ Supplement. ${ }^{(5)}$ Endectoparasiticides, antibiotics, and anti-inflammatories.

${ }^{(6)}$ Electrical energy, identification earrings, and fuel.

Feeding costs accounted for a large portion of the total production cost: $39.52 \%, 38.19 \%, 36.65 \%$, and $34.42 \%$ at the replacement levels of $0 \%, 33 \%$, $66 \%$, and $100 \%$, respectively, corroborating the reports of Bonfim et al. (2001), Possamai et al. (2015), and Taninaka et al. (2015).

As described by Alonso et al. (2017), there was no significant difference in the voluntary intake of supplement by the animals. This suggests that the average cost of a kilogram of supplements was a determining factor for the reduction in feeding expenses and, consequently, in variable costs.

The supplement in which corn was fully replaced by pearl millet had the lowest cost per kilogram (Table 1), followed by the treatments with lower replacement levels. These values resulted from the percentage decrease in soybean waste (USD 135.54 $\left.\mathrm{t}^{-1}\right)$ in the composition of the supplements as the 
level of pearl millet was elevated. Another factor that contributed to the reduction in the supplement cost was the average price of corn grain (USD $106.65 \mathrm{t}^{-1}$ ) compared to that of pearl millet grain (USD $58.17 \mathrm{t}^{-1}$ ) when purchasing the ingredients, both of which were determined in September 2010.

The quantity of concentrate supplement provided to the grazing beef cattle depends on the strategy adopted by the manager, which may aim to increase the stocking rate or even increase the individual performance of the animals. The choice for higher supplementation levels may result in an asymptotic increase in the average daily gain (ADG) so that the animals reach their sale weight early. Strategies with lower supplementation levels, on the other hand, may promote a reduction in variable costs because the basal diet costs - the forage costs - represent the majority of the feeding costs compared to the supplementary diet costs. Additionally, adopting the supplementation technique allows the pasture to be cleared faster, thus enabling its use by younger animals, which are more efficient in feed conversion.

When technically grounded, the different supplementation strategies adopted by producers are reflected in positive economic indices for the system. According to Alonso et al. (2013), the individual performance results of animals on Marandu grass pastures supplemented at $1 \%$ body weight revealed an average daily gain of $0.826 \mathrm{~kg}$ when $33 \%$ of corn grain is replaced by pearl millet grain. As stated by those authors, this result could accelerate the gain to the target of $450 \mathrm{~kg}_{\text {animal }}^{-1}$ (D450), reducing the pasture occupation time by 15 days when compared with the supplement containing $66 \%$ and $100 \%$ pearl millet grain.

Knowledge of the costs in livestock production, obtained from its systematic study, allows the manager to check whether the employment of the resources used in production is efficient. This form of management, of a business nature, leads to the application of guidelines and targets to the system, allowing one to identify and correct, when necessary, distortions observed in the livestock indices.

In this sense, the livestock index termed yield (@ $\mathrm{ha}^{-1}$ ) proves to be a response variable that provides a good reference for the efficiency of the beef cattle production activity inasmuch as it concentrates all the obtained gains in a unit of marketable body mass, weighing them by the area intended for their production.

Combined with this index, the production cost per arroba allows us to concentrate all the financial expenditures into a single variable, which makes it easier for the producer to visualize results in addition to providing a basis for a comparative accounting of the livestock business.

The results shown in Table 3 corroborate the inferences by Moraes and Wernke (2006) about the application of UCM as an important accounting index to observe the returns obtained from each product of the analyzed company. In this study, the product was considered to be one of the supplementary treatments.

The highest UCM index was obtained for a replacement level of $66 \%$, followed by the $33 \%$ level. These values show that the intermediate level of substitution may provide greater returns per arroba sold, that is, this index is the unit sale price after the variable costs are subtracted (eq. 3 ) and corresponds to the monetary amount available mainly for amortizing the fixed expenses and, subsequently, for generating profit. Therefore, the weight of the sold animals that consumed the supplement with $66 \%$ of the corn replaced by pearl millet was $5.52 \%$, $1.39 \%$, and $3.39 \%$ higher than that of the animals that consumed the treatments with $0 \%, 33 \%$, and $66 \%$ replacement levels, respectively, providing a greater surplus for profit generation. Although the results with the $33 \%$ replacement level were inferior to those with the $66 \%$ level, the latter exhibited a $4.08 \%$ and $1.97 \%$ higher UCM than that of the treatments with $0 \%$ and $100 \%$ replacement levels, respectively. 
Table 3. Livestock indices, revenue, and accounting indices in the production of beef cattle supplemented with increasing levels of pearl millet replacing corn.

\begin{tabular}{|c|c|c|c|c|c|}
\hline \multirow{2}{*}{ Description } & \multirow{2}{*}{ Unit } & \multicolumn{4}{|c|}{ Pearl millet level (\%) } \\
\hline & & 0 & 33 & 66 & 100 \\
\hline Average daily weight gain ${ }^{(1)}$ & $\mathrm{kg}$ animal $^{-1}$ day $^{-1}$ & 0.816 & 0.826 & 0.797 & 0.691 \\
\hline Total weight gain ${ }^{(1)}$ & (a) animal $^{-1}$ & 2.28 & 2.31 & 2.23 & 1.93 \\
\hline Yield $^{(2)}$ & @ ha ${ }^{-1}$ & 7.79 & 7.90 & 7.62 & 6.60 \\
\hline Revenue $^{(3)}$ & USD $_{\text {animal }}{ }^{-1}$ & 110.01 & 111.36 & 107.45 & 93.16 \\
\hline Unit contribution margin (UCM) & USD @ ${ }^{-1}$ & 28.95 & 30.13 & 30.55 & 29.55 \\
\hline Accounting break-even point ( $\mathrm{ABPq})$ & @ & 0.87 & 0.83 & 0.84 & 1.01 \\
\hline Accounting break-even point $\left(\mathrm{ABP}_{s}\right)$ & USD & 41.89 & 39.97 & 40.45 & 48.63 \\
\hline Financial break-even point (FBPq) & @ & 0.64 & 0.61 & 0.62 & 0.74 \\
\hline Financial break-even point $\left(\mathrm{FBP}_{\$}\right)$ & USD & 30.81 & 29.37 & 29.85 & 35.63 \\
\hline Margin of safety (MSq) & @ & 1.41 & 1.49 & 1.39 & 0.93 \\
\hline Margin of safety $\left(\mathrm{MS}_{\mathrm{s}}\right)$ & USD & 67.89 & 71.75 & 66.93 & 44.78 \\
\hline Shutdown point (SP) & (a) & 0.22 & 0.21 & 0.21 & 0.26 \\
\hline
\end{tabular}

Source: Created by the author, based on Alonso et al. (2013).

*Note: ${ }^{(1)}$ Data obtained from Alonso et al. (2013). ${ }^{(2)}$ Yield $=($ Total weight gain $\times 16$ animals $) /($ area allocated to production $(4.68$ ha)). ${ }^{(3)}$ Revenue $=$ Total weight gain $\times($ average price of an arroba of the fattened cattle (paid in cash) $($ USD 48.15)).

The number of arrobas sold and the amount of money necessary to cover all the production costs without generating profit were provided by the $\mathrm{ABPq}$ and $\mathrm{ABP}_{\mathrm{S}}$ accounting index, respectively. As can be observed in Table 3, the supplementary treatments with $33 \%$ and $66 \%$ substitutions led to lower $\mathrm{ABPq}$ and $\mathrm{ABP}_{\$}$, which allows us to consider them as replacement levels with better performance than that of the treatments with $0 \%$ and $100 \%$ levels.

At the same time, the dietary supplements increased total weight gain and revenue. Therefore, in the context of the present study, where the taxation of livestock production was not taken into account, all treatments would create profit for the system, for the earnings and quantity of arrobas sold that exceeded $\mathrm{ABP}_{\$}$ and $\mathrm{ABPq}$.

$\mathrm{FBP}_{\$}$ and $\mathrm{FBPq}$ reflect how much a company needs to sell to cover all cash charges without any profit, that is, these indices allow us to determine the operational level at which the company will be financially balanced. The $\mathrm{FBP}_{\$}$ and $\mathrm{FBPq}$ indices were lower for the supplementation treatments with
$33 \%$ and $66 \%$ replacement levels, indicating these levels are more attractive, since the farmer would have to sell fewer arrobas and, consequently, need a lower revenue to cover the costs incurring cash outlay.

It is noteworthy that the use of the financial break-even point is an easily adopted evaluation, which provides information of great relevance to companies. However, the use of this indicator in the cost-analysis context should depend on what type of information the manager is interested in, since, according to Martins (2006), upon reaching the financial break-even point, the company achieves a cash balance but not an accounting balance. This is because the computation of this indicator does not include non-cash charges, such as the depreciation of fixed assets.

For the $\mathrm{MSq}$ and $\mathrm{MS}_{\mathrm{S}}$ indicators, the supplementary treatment with a replacement level of $33 \%$ yielded greater returns compared to those with levels of $0 \%, 66 \%$, and $100 \%$. Considering that the margin of safety demonstrates the company's 
situation and that it is based on the break-even point, results for $\mathrm{MSq}$ and $\mathrm{MS}_{\mathrm{S}}$ corroborate those found for $\mathrm{ABPq}$ and $\mathrm{ABP}_{\$}$. On this basis, the supplement with $33 \%$ of corn replaced by pearl millet ensured, in addition to the payment of the production costs involved, a greater profit for the system compared to the other evaluated supplements.

When we compared the treatment with $0 \%$ substitution to the one wherewith $66 \%$ of corn was replaced by pearl millet, we observed that the inclusion of the latter ingredient resulted in a higher margin of safety according to the MSq and $\mathrm{MS}_{\mathrm{S}}$ indicators. These results were the opposite of those based on the $\mathrm{ABPq}$ and $\mathrm{ABP}_{S}$ indices, where the replacement level of $0 \%$ showed a higher breakeven point compared to the $66 \%$ level, indicating the former is less attractive. This effect is explained by the margins of safety, which use the quantity of arrobas sold as a predictive variable (eq. 8). As a result, the treatment with zero substitution led to better animal performance - that is, total weight gain - compared to the treatment with a $66 \%$ replacement, which yielded a larger volume of sales, resulting in more attractive values of $\mathrm{MSq}$ and $\mathrm{MS}_{\$}$.

All the supplements resulted in a lower SP value than that obtained with the animal performance without the treatments, thus not justifying the discontinuation of concentrate supplementation, even temporarily, and irrespective of the level of substitution of the energy ingredients. In this case, the production system should only cease to use supplementation in the pasture-based fattening stage if production were lower than 0.22, 0.21, 0.21, and $0.26 @$ for the supplements with replacement levels of $0 \%, 33 \%, 66 \%$, and $100 \%$, respectively.

The lowest SP values were obtained with the replacement levels of $33 \%$ and $66 \%$. These results were due to the higher UCM of these treatments, since the fixed avoidable costs (e.g., labor) were similar for all lots of animals consuming the different supplements. These values indicate that the intermediate substitution levels promoted greater returns per arroba sold, at values sufficient to cover their specific fixed costs and part of the non-avoidable fixed costs allocated to them.

In addition to revenues, the knowledge and analytical assessment of the production costs of a livestock company are factors of great relevance as regards the effectiveness of the management of a rural property. On these grounds, it is of paramount importance that the producer and entrepreneur maintain a precise cost-control system to plan the expense accounting of the production activity.

The present results allowed for a systemic evaluation of the information under the CVP perspective, allowing the identification of supplements that would yield greater profits. This broadens the choice for a better treatment, as it considers not only the animal performance as a crucial component but also the financial performance of the economic activity. Moreover, this analysis is not limited to case studies; because of its versatility, it can be employed in experimental investigations, which has not been exploited much in animal production research.

Based on the indicators presented, it can be determined that the supplementation technique at the level of $1 \%$ body weight, at all replacement levels, could be profitable for the pasture-finished beef cattle system under the crop-livestock integration strategy. Alonso et al. (2013) reported that the best production performances were obtained for animals consuming supplements in which 33\% of the corn grain had been replaced by pearl millet grain. Corroborating those authors' results, this study indicated that the same replacement level yielded higher $\mathrm{UCM}, \mathrm{MSq}$, and $\mathrm{MS}_{\$}$ values and lower $\mathrm{ABPq}, \mathrm{ABP}_{\$}, \mathrm{FBPq}, \mathrm{FBP}_{\S}$, and $\mathrm{SP}$ values, suggesting that this supplementation level exhibits the greatest financial attractiveness.

These results demonstrate that the accounting indices presented here were more dependent on the actual production performance (Table 3) than on the cost of the cheaper supplement (Table 1). This suggests that producing under a minimal-costs 
concept, specifically in terms of feeding, may not lead to better financial results for the system.

It is noteworthy that this result is temporal and should thus not be taken as a reference for yearround conditions, since the cost of the ingredients for the formulation of the supplements, the animal performance, and the quantity and quality of pasture are not static and are altered by different agents external to the system.

\section{Conclusions}

The systemic cost-volume-profit analysis is a useful tool in experimental evaluations, as it determines the most profitable factor.

Dietary concentrate supplements with $33 \%$ of corn grain replaced by pearl millet grain are financially more attractive for the pasture finishing of beef cattle in a crop-livestock integration system because of the higher returns obtained.

\section{References}

ALONSO, M. P.; MORAES, E. H. B. K.; PEREIRA, D. H.; PINA, D. S.; MOMBACH, M. A.; HOFFMANN, A.; GIMENEZ, B. M.; SANSON, R. M. M. Pearl millet grain for beef cattle in crop-livestock integration system: intake and digestibility. Semina: Ciências Agrárias, Londrina, v. 38, n. 3, p. 1461-1472, 2017. DOI: 10.5433/1679-0359.2017v38n3p1471

ALONSO, M. P.; MORAES, E. H. B. K.; PINA, D. S.; PEREIRA, D. H.; HOFFMANN, A.; SANSON, R. M. M.; WRUCK, F. J. Grão de milheto em suplementos para terminação de bovinos de corte em sistema integração lavoura e pecuária. Revista Brasileira de Saúde e Produção Animal, Salvador, v. 14, n. 12, p. 350-361, 2013. DOI: $10.1590 / \mathrm{S} 1519-99402013000200010$

BONFIM, M. A. D.; REZENDE, C. A. P.; PAIVA, P. C. A.; ANDRADE, I. F.; MUNIZ, J. A.; SILVA, A. R. P. Níveis de concentrado na terminação de novilhos holandês x zebu suplementados a pasto na estação seca. Ciência e Agrotecnologia, Lavras, v. 25, n. 6, p. 14571466, 2001.

BORNIA, A. C. Análise gerencial de custos: aplicação em empresas modernas. São Paulo: Editora Atlas, 2010. 214 p.

BRUNI, A. L.; FAMÁ, R. Gestão de custos e formação de preços: com aplicações na calculadora HP $12 \mathrm{C}$ e Excel. São Paulo: Editora Atlas, 2010. 596 p.

BRASIL. Instrução Normativa RFB $\mathrm{n}^{\circ}$ 1700. Diário Oficial [da] União, Brasília. Seção 1, 2017. p. 23.

FIGUEIREDO, D. M.; OLIVEIRA, A. S.; SALES, M. F. L.; PAUlinO, M. F.; VAlE, S. M. L. R. Análise econômica de quatro estratégias de suplementação para recria e engorda de bovinos em sistema pastosuplemento. Revista Brasileira de Zootecnia, Viçosa, MG, v. 36 , n. 5 , p. 1443-1453, 2007. DOI: $10.1590 /$ S1516-35982007000600030

INSTITUTO MATO-GROSSENSE DE ECONOMIA AGROPECUÁRIA - IMEA. Boletim semanal - análise bovinocultura. Cuiabá: Editora IMEA, 2010. n. 121. Disponível em: http://www.imea.com.br /upload/ publicacoes/arquivos/2010_09_24_BSBoi.pdf. Acesso em: 14 mar. 2017.

MARION, J. C. Contabilidade rural: contabilidade agrícola, contabilidade da pecuária, imposto de renda pessoa jurídica. São Paulo: Editora Atlas, 2010. 254 p.

MARTINS, E. Contabilidade de custos. São Paulo: Editora Atlas, 2006. 370 p.

MORAES, L. C.; WERNKE, R. Análise custo/volume/ lucro aplicada ao comércio de pescados. Revista Contemporânea de Contabilidade, Florianópolis, v. 1, n. 6, p. $81-101,2006$. DOI: $10.5007 / \% 25 x$

POSSAMAI, A. J.; ZERVOUDAKIS, J. T.; CABRAL, L. S.; OLIVEIRA, A. S.; HATAMOTO-ZERVOUDAKIS, L. K.; FREIRIA, L. B.; DONIDA, E. R.; KOSCHECK, J. F. W.; SILVA, P. I. J. L. R.; MELO, A. C. B. Glicerina bruta e caroço de algodão em suplementos múltiplos para terminação de bovinos à pasto na época das águas. Análise econômica. Archivos de Zootecnia, Córdoba, v. 64, n. 246, p. 109-116, 2015. DOI: 10.21071/az.v64i246.384

SOUZA, A.; CLEMENTE, A. Gestão de custos: aplicações operacionais e estratégicas: exercícios resolvidos e propostos com utilização de Excel. São Paulo: Editora Atlas, 2011. 280 p.

STARK, J. A. Contabilidade de custos. São Paulo: Editora Pearson Prentice Hall, 2008. 378 p.

TANINAKA, T.; BERNARDINO, T.; MENEGHINI, R.; SANTOS, G. Análise da viabilidade econômica de um rebanho de gado de corte da raça Wagyu em ciclo completo. Revista iPecege, Piracicaba, v. 1, n. 2, p. 4458, 2015. DOI: $10.22167 /$ r.ipecege.2015.2.44

WARREN, C. S.; REEVE, J. M.; FESS, P. E. Contabilidade gerencial. São Paulo: Editora Thomson Learning, 2008. 587 p.

WERNKE, R. Gestão de custos: uma abordagem prática. São Paulo: Editora Atlas, 2004. 175 p. 
